\title{
Foreword to the special section on implications of the COVID pandemic
}

\author{
PÉTER MARTON
}

Department of International Relations, Corvinus University of Budapest, Budapest, Hungary

(C) 2021 The Author(s)

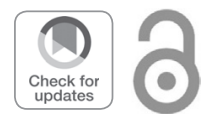

Peer-reviewed academic journals and special issues are no easy match to make. Special occasions beget special issues, and such occasions are often fleeting moments compared to the lengthy process of peer-review. By the time (and if) articles worthy of publishing are submitted, evaluated, revised, edited, and finally approved, history may have moved on. As is often cited, U.S. scholarturned-statesman Henry Kissinger once suggested that "the analyst runs no risk [...] if his conclusions prove wrong, he can write another treatise". However, time is not really on the side of the scholar. One's conclusions and even the apropos for the quest for those conclusions may become outdated - and then the cycle of treatise-writing and review cannot simply begin anew.

In calling for articles for a special issue related to the pandemic of the novel coronavirus back in 2020 , we ran several risks. One is that people might think that we, the editors, have simply jumped on the bandwagon and aimed to cover a subject that everyone else was keen on covering at the same time - there is no shortage of similar COVID-related special issues in the world of academic publishing at the moment. The second risk was that we may not get enough submissions in a saturated market, where scholars may have had plenty of targets to choose from, to try to place their manuscripts. A third risk involved not getting good enough quality at a time of public-health-related restrictions and risks related to movement - consequently, a time of limited research opportunities.

Some also seemed to think that we ran a fourth type of risk, of the kind alluded to above. Namely, that the pandemic might have ended by now, had those sceptics been right. From university administrations eager to get back to in-person teaching after years and years of a push for the increasing digitalisation of curricula, to influential critics of public health measures, many argued at the time when we issued our call for a COVID-related special issue in the summer of 2020 that the novel coronavirus could only conceivably produce the one major wave we saw in spring 2020, the one that was effectively broken by lockdowns by the summer of that year. Citing serological survey sample data of questionable validity and other cherry-picked facts and arguments, many opined that a great share of the world's population had already been infected without severe consequences, overestimating the prevalence of asymptomatic carriers of the virus, along with the pathogen's harm to human health. These predictions proved wrong and,

\footnotetext{
*Corresponding author. E-mail: peter.marton@uni-corvinus.hu
} 
sadly, events have validated our assessment of what to expect. The subject certainly does not count as outdated at the time of writing this foreword.

One voice heralding the soon-to-be end of a not-particularly-severe pandemic was British financial historian Niall Ferguson, author of one of the first major English-language books to try to make sense of the COVID crisis from the side of the humanities, titled Doom: The Politics of Catastrophe (Ferguson 2021; he completed his manuscript in the summer of 2020). Even as he was wrong on a number of counts, Ferguson has to be commended for the wisdom of seeing the need to step beyond disciplinary confines to offer a synthesis of an interpretation of how the pandemic emerged, and that social scientists and historians have much to add to the required drawing of lessons, alongside researchers from fields such as virology or the medical sciences, thought by many to somehow own the subject by exclusive right. Similar considerations motivated my Hungarian-language book on the subject, titled COVID-19: The Scourge of Unhealthy Policies (in Hungarian, titled: COVID-19: Az egészségtelen politikák ragálya; Marton 2021).

These considerations were also drivers of the present special section project - to stimulate the inevitably necessary engagement of the social sciences with the subject of a crisis that had as many, if not also more important, social and political determinants as biological ones. Take but the example of the lack of sufficient international cooperation on crafting a truly coordinated strategy of global pandemic response, on the sharing of vaccines and other medical equipment, or in providing sufficient aid to those countries that were hit particularly hard or had limited capacities to mount effective measures. Moreover, the current pandemic was and is a crisis that has had and continues to have an extremely broad range of political, economic, social, cultural and other ramifications that need to be addressed by the social sciences - hence there being even more of a good reason to launch an effort like this.

What we present here is a special thematic section in the current issue of Society and Economy, with three articles that even in their diversity are held together by a focus on the above mentioned societal implications of the present crisis.

Cristian Vlas looks at the health system in Transnistria and how it can cope with a number of major challenges, including the pandemic - drawing attention to a key global public health challenge of an international political nature: that there are considerable gaps in the universal coverage of global health institutions in the form of non-recognised de facto states. David Morris examines, through the example of the Asian Infrastructure Investment Bank, the question of what we may expect from China in its contestation of the basic principles and institutions of global governance - reform or revolution? This holds much relevance against the backdrop of increasing geopolitical tensions between the People's Republic and the West (especially, but not only, with the United States of America), tensions further fuelled by the complex consequences of the COVID crisis and complicated by a dynamically shifting U.S. approach to global leadership. Bence Kiss-Dobronyi, Dóra Fazekas and Hector Pollitt consider the future of a postCOVID world in a normative sense, offering an analysis of the varied prospective impact of a green approach to economic recovery in the Visegrad Four countries.

We are convinced that these articles hold valuable contributions to the larger volume of social-sciences-based scholarship about the pandemic that is and will be emerging in the coming period, and, with that, we wish readers fruitful engagement with the resulting special thematic section. 


\section{REFERENCES}

Ferguson, N. (2021): Doom: The Politics of Catastrophe. London: Penguin Press.

Marton, P. (2021): COVID-19: Az egészségtelen politikák ragálya [The Scourge of Unhealthy Policies]. Budapest: Progress Könyvek.

Open Access. This is an open-access article distributed under the terms of the Creative Commons Attribution-NonCommercial 4.0 International License (https://creativecommons.org/licenses/by-nc/4.0/), which permits unrestricted use, distribution, and reproduction in any medium for non-commercial purposes, provided the original author and source are credited, a link to the CC License is provided, and changes - if any - are indicated. 